\title{
The Impact and Treatment of Night Soil in Anaerobic Digester: A Review
}

\author{
Antony Daisy ${ }^{1 *}$ and S.Kamaraj ${ }^{2}$ \\ ${ }^{1}$ Antony Daisy, Tamil Nadu Agricultural University, Coimbatore, Tamil Nadu, India \\ ${ }^{2}$ Directorate of Research, Tamilnadu Agricultural University, Coimbatore-641003. Tamilnadu, India
}

\begin{abstract}
With the aim of improving knowledge about the stability and reliability of anaerobic night soil treatment systems, several researchers have studied the effects of different digester design and operational performance of such digester. In general, anaerobic digesters are affected by changes in external factors, but the severity of the effect is dependent upon the type, magnitude, duration and frequency of the imposed changes. Special attention is paid to the advantages of anaerobic digestion in limiting the emission of greenhouse gases This review summarises the causes, generation rate of night soil , composition of slurry, pathogen and its harmful effects and effects of operation in different digester on anaerobic night soil treatment systems. However, there still remain some unclear technical and scientific aspects that are necessary for the improvement of the stability and reliability of anaerobic processes. An overview of research achievements and future developments is given.
\end{abstract}

Keywords: Night soil; BOD (Biological Oxygen Demand); COD (Chemical Oxygen Demand); Faeces; Human Excreta; Anaerobic digester

\section{Introduction}

In today's energy crisis, it is recognized that renewable energy sources can be the alterable sources of energy to provide the basis for sustainable energy development on account of their inexhaustible nature and environment-friendly features [1]. The challenge now is to implement the latest technology at the grass root level effectively. Additionally the economy of biogas plants can be improved by using high biogas potential substrates in combination with cattle dung [2]. One such substrate being night soil, rich in nitrogen content was added to the cattle dung digesters to combat the nitrogen deficiency and also improve the gas production [3,4]. Another thing is human waste disposal in an innocuous form in highly populated and developing countries, such as India is an ever growing problem [5]. Improper disposal of human excreta results in the contamination of water bodies, soil and food crops. This practice poses a serious health hazard because human excreta is the principal source of pathogenic organisms, which may be transmitted by direct contact, contaminated water and food, insects and other vectors. Human excreta must therefore be treated before its ultimate disposal into the environment or its use in agriculture in order to reduce the spread of communicable diseases caused by excreted pathogenic organisms and prevent the pollution of the environment, water sources and soil [6].

The problem of treatment and disposal is more aggravated at low temperature and high altitude regions, such as Himalayan regions of India, where no proper human waste disposal method is in practice. Although, aerobic degradation of organic waste is considered to be efficient, anaerobic digestion appears to be more suitable in view of the generation of biogas which can be used for maintenance of digester temperature (in addition to better hygiene) with least human intervention [7]. The main advantage of anaerobic digestion technology is regarded as a good alternative for human and animal waste treatment and has advantages over the other methods due to generation of fuel (methane) and rich organic manure (digested sludge) [8,9].

\section{Night soil}

Nightsoil is mostly used to represent, in general, a mixture of human faeces and urine. In certain instances, the term is also used to represent a mixture of human faeces and urine that has undergone some considerable putrefaction. Pradt, Mara, Satyanarayan et al. and Choi et al. [10-14] had used the term for a mixture of human faeces and urine. Mara and Caincross [15] used the term for "a mixture of human faeces and urine transported without flushing water". Caincross and Feachem [16] stated that "night soil comprises only faeces and urine plus small volumes of water if it is used for anal cleansing and pour flushing". Stoll and Parameswaran [17] referred to the contents from septic tanks/leaching pits which were connected to pour flush latrines in Bangkok as night soil. Choi et al. [18] used the term for contents of cesspool and holding tanks/storage pits in. Some of the listed references indicated how loosely the term night soil was used by some authors. It is desirable to use the term consistently and in a specific manner in standard technical texts and literature. This would help in the search for and sharing of information from research findings. In this study, night soil is used for "a mixture of human faeces and urine that is mostly fresh".

\section{Human excreta}

Human excreta consist of faeces and urine. The two are waste products of the bodily metabolism. The appearance, physical and chemical characteristics of urine or faeces depend largely on the health of the person excreting the material, as well as on the amount and type of food and liquid consumed $[19,20]$. Therefore, the excreta generated by healthy people eating a similar diet are quite similar in both physical and chemical composition. In a study on the composition of human excreta, it was reported that age, sex, occupation or religion did not affect the chemical composition of the different fractions. However, a significant variation was that older people excreted larger amounts of total wet matter than younger, which was linked to a larger water intake intended to reduce the risk of constipation [21].

\section{Faeces}

Faeces consist of material that passes through the intestines undigested, mixed with material extracted from the blood stream or shed from glands and the intestines [22]. Faeces are malodorous and

*Corresponding author: Antony Daisy, Tamil Nadu Agricultural University, Coimbatore, Tamil Nadu, India, E-mail: daisy_ageg@yahoo.com

Received October 30, 2010; Accepted December 18, 2010; Published April 28 2011

Citation: Daisy A, Kamaraj S (2011) The Impact and Treatment of Night Soil in Anaerobic Digester: A Review. J Microbial Biochem Technol 3: 043-050. doi:10.4172/1948-5948.1000050

Copyright: ( 2011 Daisy A, et al. This is an open-access article distributed under the terms of the Creative Commons Attribution License, which permits unrestricted use, distribution, and reproduction in any medium, provided the original author and source are credited 
consist, in addition to the undigested material, of mucus and cells shed from the intestines as well as bile, which give them their characteristic brown colour [23]. Faeces contain mainly water, bacteria, nutrients and food residues [19]. They can also contain large concentrations of pathogenic viruses, cysts of protozoa and eggs of helminths [20].

\section{Urine}

Urine is the excreta fraction that is filtered from the blood and combined with excess water by the kidneys [22]. At excretion, urine is usually yellow and does not have a foul smell $[24,25]$ but when stored it acquires a pungent odour as the urea breaks down to ammonia and carbon dioxide due to bacterial action [25]. Urine largely consists of water, approximately 93-96\% [26,27], and large amounts of nutrients that are mainly in water-soluble form [28] (Table 1).

\section{Nutrients in faeces}

The nutrient content of faeces originates from the food consumed. For $\mathrm{P}$, calcium $(\mathrm{Ca})$ regulates the amount of $\mathrm{P}$ available for uptake by the digestive system [29]. It is estimated that the food nutrient content is distributed to the faecal fraction in the proportions: $10-20 \% \mathrm{~N}, 20$ $50 \% \mathrm{P}$ and $10-20 \% \mathrm{~K}[30,19,22,29]$. About $20 \%$ of the faecal nitrogen is ammonia, biochemically degraded from proteins, peptides and amino acids, some $17 \%$ is found in living bacteria and the remainder is organic nitrogen combined in molecules such as uric acid and enzymes [19].

\section{Nutrients in urine}

Urine contains the largest proportion of plant nutrients found in the household waste fractions. The amount of plant nutrients excreted via urine per person and year has been measured at $2.5-4.3 \mathrm{~kg}$ nitrogen $(\mathrm{N}), 0.4-1.0 \mathrm{~kg}$ phosphorus $(\mathrm{P})$ and $0.9-1.0 \mathrm{~kg}$ potassium $(\mathrm{K})[19,31$ 33]. Vinneras et al. [33] combined their own measurements on the nutrient content of urine with previous studies and found that the annual excretion rate per person in Sweden was about $4000 \mathrm{~g} \mathrm{~N}, 365$ $\mathrm{g} \mathrm{P}$ and $1000 \mathrm{~g} \mathrm{~K}$, corresponding to $11 \mathrm{~g} \mathrm{~N} / \mathrm{p}, \mathrm{d}, 1.0 \mathrm{~g} \mathrm{P} / \mathrm{p}, \mathrm{d}$ and 2.7 $\mathrm{g} \mathrm{K} / \mathrm{p}$,d. Jonsson et al. [32] evaluated previously published studies on urine and on food consumption and arrived at similar values, except for phosphorus, which was estimated at $0.9 \mathrm{~g} / \mathrm{p}, \mathrm{d}$.

\section{Generation rate of faeces}

Approximately $30-45 \mathrm{~kg}$ (wet weight basis) of faeces produced per person and year in developed countries, corresponding to $10-15 \mathrm{~kg}$ of dry matter [19,20-22,32]. Del Porto and Steinfeld compiled data from several studies and reported an average faecal excretion rate of $150 \mathrm{~g} / \mathrm{p}, \mathrm{d}$. The amount of faeces produced depends on the composition of the food

\begin{tabular}{|l|l|l|}
\hline Approximate Quality & Faeces & Urine \\
\hline Water content in the night soil (per capita) & $135-270$ gram & $1.0-1.3$ litre \\
\hline Approximate Composition & (Dry Basis) & \\
\hline $\mathrm{PH}$ & $5.2-5,6$ & \\
\hline Moisture (\%) & $66-80$ & $93-96$ \\
\hline Solids & $20-34$ & $4-7$ \\
\hline Composition of Solids & & \\
\hline Organic matter, \% & $88-97$ & $65-85$ \\
\hline Nitrogen (N), \% & $5-7$ & $15-19$ \\
\hline Potassium (K), \% & $0.83-2.1$ & $2.6-3.6$ \\
\hline Carbon. \% & $40-55$ & $11-17$ \\
\hline Calcium (Ca), \% & $2.9-3.6$ & $3.3-4.4$ \\
\hline C/N ratio & $5-10$ & $0.6-1.1$ \\
\hline
\end{tabular}

*Phosphorous is conspicuously absent in the report

Table 1: Quality and Composition of Human Faeces and Urine*.

\begin{tabular}{|l|l|}
\hline Age group & Excreta production/day \\
\hline Adult (15 years or above) & $0.4 \mathrm{~kg}$ (based on literature review) \\
\hline 10 to 15 years & $0.3 \mathrm{~kg}$ (interpolated/estimated) \\
\hline 6 to 10 years & $0.2 \mathrm{~kg}$ (interpolated/estimated) \\
\hline
\end{tabular}

Table 2: Available Human Excreta as per age group.

consumed. Foods low in fibre such as meat and other products result in smaller amounts (mass and volume) of faeces [22]. Faecal excretion rates in developed countries are lower than those in developing countries, with excretion rates for Americans and Europeans estimated at between 100 and $200 \mathrm{~g} / \mathrm{p}, \mathrm{d}$. While for developing countries estimates are on average $350 \mathrm{~g} / \mathrm{p}, \mathrm{d}$ in rural areas and $250 \mathrm{~g} / \mathrm{p}$, d in urban areas [20]. In China, Gao et al. [35] measured 315 g/p,d while Pieper [36] measured 520 g/p,d in Kenya. In measurements by Schouw et al. [21] in Southern Thailand, wet faecal generation rates were found to be 120 $400 \mathrm{~g} / \mathrm{p}$,d. Vinneras et al. [27], using measurements from two blocks of flats in Sweden, estimated faecal excretion rate at $140 \mathrm{~g} / \mathrm{p}, \mathrm{d}$ amongst the Swedes, and water content at about $78 \%$. At faecal excretion rates between 100 and $150 \mathrm{~g} / \mathrm{p}, \mathrm{d}$, water content is about $75 \%$, but this increases with increasing weight, and is approximately $90 \%$ at faecal weights of $500 \mathrm{~g} / \mathrm{p}, \mathrm{d}$ [20]. Faecal excretion is on average one stool per person and day, but it may vary from one stool per week up to five stools per day [19,37].

\section{Generation rate of urine}

Urine is used by the body as a balancing medium for liquids and salts and the amount of urine excreted by a person therefore varies [28]. The quantity excreted depends on how much a person drinks and sweats, and also on other factors such as diet, physical activity and climate $[19,20]$. Excessive sweating results in concentrated urine, while consumption of large amounts of liquid dilutes the urine. Feachem et al. [20] reported that the urine generation rate for most adults is between 1.0 and $1.3 \mathrm{~kg}$ per person and day $(\mathrm{kg} / \mathrm{p}, \mathrm{d})$.

\section{Available human excreta as per age group [38]}

It is not surprising that the per capital quantities, as reported in the literature, vary widely. Figures for collected septate, i.e., fecal sludge stored in septic tanks, can be as low as 0.3 litre/persons/day and as high as $131 /$ litres/person/day. Most of the reported values vary between 0.5 and 1 litres/person/day and the excreta production as per age group is classifies as given below [38] (Table 2).

\section{Night soil based biogas}

Potential of biogas from human waste is $0.07 \mathrm{~m}^{3} / \mathrm{kg}$ in Bangladesh [39] .Guidebooks reported that Biogas generated from Human excreta is $0.020-0.028 \mathrm{~m}^{3} / \mathrm{kg}[40,41]$ (Table 3).

\section{Composition of spent slurry from night-soil biogas plant}

Many families in the developing countries except China have some reservation or social constraint to utilize human excreta or digested sludge produced from latrine-attached plant. Attaching latrine with biogas plants has two fold benefits: (i) the disposal problem of human waste that is hazardous to human health is solved thereby improving environment and sanitation; and (ii) additional amount of gas as well as manure is produced as a result of using latrine waste in conjunction with animal dung. A comparison of the analytical data presented in table, that the percentage of major plant nutrients (NPK) contained in the spent slurry from night soil biogas plant is fairly higher than those with only the cow dung plant [42] (Table 4). 
Citation: Daisy A, Kamaraj S (2011) The Impact and Treatment of Night Soil in Anaerobic Digester: A Review. J Microbial Biochem Technol 3: 043-050. doi:10.4172/1948-5948.1000050

\section{Pathogens and its harmful effects}

Most pathogenic or potentially intestinal pathogenic micro organisms enter a new host by ingestion (water, food, fingers, dirt on lips, aerosols caught in the nose and swallowed) or through the lungs (after inhalation of aerosol particles) or through the eye (when eyes are rubbed with contaminated fingers) [20], while others may also enter through the skin or wounds. After infecting the host, large numbers of pathogens may be excreted. Depending on the health of the population, several species of pathogenic bacteria, viruses, parasitic protozoa and helminths may be found in the faeces from the population and thus also in its mixed wastewater. From a hygiene point of view, any exposure to faeces constitutes a risk $[20,43,44]$. The selected pathogen that may be excreted in faeces and disease and symptoms they cause [45] are given in (Table 5).

The kill rates of pathogens at different temperature and retention time during anaerobic fermentation [46] (Table 6).

\section{Basic concepts of anaerobic digestion}

Basically, anaerobic digestion is a bacterial fermentation process by which organic material is broken down in the absence of dissolved oxygen to produce stable end-products, mainly methane and carbon dioxide [47,48]. Van Haandel and Lettinga [49] referred to the process as the ultimate fermentative process because it is characterised by the production of methane, which is the most reduced organic compound. For an organic matter $\mathrm{CxHyOz}$, the process of anaerobic digestion can be written as:

$$
\begin{aligned}
& \mathrm{CxHyOz}+1 / 4(4 \mathrm{x}-\mathrm{y}-2 \mathrm{z}) \mathrm{H}_{2} \mathrm{O} \rightarrow 1 / 8(4 \mathrm{x}-\mathrm{y}-2 \mathrm{z}) \mathrm{CO}_{2}+1 / 8(4 \mathrm{x}-\mathrm{y}-2 \mathrm{z}) \\
& \mathrm{CH}_{4}
\end{aligned}
$$

During the process of anaerobic digestion, only a minor fraction of the chemical energy in the organic matter is released, the major part remaining as chemical energy in the methane produced. McInerney et al. [63] calculate that about $90 \%$ of the available energy in the organic matter is retained in the methane produced as illustrated in the following example using acetic acid [49]: during the oxidation of acetic acid with oxygen, the free energy released is equal to $207 \mathrm{kcal} \mathrm{mol}^{-1}$ in the reaction

$$
\mathrm{C}_{2} \mathrm{H}_{4} \mathrm{O}_{2}+2 \mathrm{O}_{2} \rightarrow 2 \mathrm{CO}_{2}+\mathrm{H}_{2} \mathrm{O}+207 \mathrm{kcal}
$$

Similarly, during the oxidation of methane with oxygen, the free energy released is equal to $191 \mathrm{kcal} \mathrm{mol}^{-1}$ in the reaction

$$
\mathrm{CH}_{4}+2 \mathrm{O}_{2} \rightarrow 2 \mathrm{CO}_{2}+2 \mathrm{H}_{2} \mathrm{O}+191 \mathrm{kcal}
$$

\begin{tabular}{|l|l|}
\hline Composition & Percentage \\
\hline Methane & $65-66 \%$ \\
\hline carbon oxide & $32-34 \%$ \\
\hline hydrogen sulphide & $1 \%$ \\
\hline nitrogen oxide & Trace \\
\hline ammonia & Trace \\
\hline
\end{tabular}

\begin{tabular}{|c|c|c|}
\hline Group & Pathogen & Disease \\
\hline Bacteria & $\begin{array}{l}\text { Aeromonas spp } \\
\text { Camplyobacter jejumi/coli } \\
\\
\text { Escherichiacoli } \\
\text { (EIEC,EPEC,ETEC, EHEC) } \\
\text { Salmonella typhi/paratyphi } \\
\text { Salmonella spp. } \\
\text { Shigella spp. } \\
\text { Vibrio cholerae }\end{array}$ & $\begin{array}{l}\text { Enteritis } \\
\text { Campylobacteriosis-diarrhoea, } \\
\text { cramping, abdominal pain, fever, } \\
\text { nausea, arthritis, Guillain-Barre } \\
\text { syndrome } \\
\text { Enteritis. For EHEC there are also } \\
\text { internal haemorrhages that are } \\
\text { sometimes lethal } \\
\text { Typhoid/ paratyphoid fever- headache, } \\
\text { fever, malaise, anorexia, brady cardia, } \\
\text { splenomegaly, cough } \\
\text { Salmonellosis- diarrhoea, fever- } \\
\text { abdominal cramps } \\
\text { Shigellosis-dysentery (bloody } \\
\text { diarrhoea), Vomiting, Cramps, fever, } \\
\text { reiter's syndrome } \\
\text { Cholera-watery diarrhoea, lethal if } \\
\text { severe and untreated }\end{array}$ \\
\hline Virus & $\begin{array}{l}\text { Adenovirus } \\
\text { Enteric adenovirus } 40 \& 41 \\
\text { Enterovirus types } 68-71 \\
\text { Hepatitits A } \\
\text { Hepatitits E } \\
\text { Poliovirus } \\
\text { Rotavirus }\end{array}$ & $\begin{array}{l}\text { Various; respiratory illness, here added } \\
\text { due to enteric types (see below) } \\
\text { Enteritis } \\
\text { Meningitis; encephalitis; paralysis } \\
\text { Hepatitits-fever, malaise, anorexia, } \\
\text { nausea, abdominal discomfort, } \\
\text { jaundice } \\
\text { Hepatitits } \\
\text { Poliomyelitis- often asymptomatic, } \\
\text { fever, nausea, Vomiting, headache, } \\
\text { paralysis } \\
\text { Enteritis }\end{array}$ \\
\hline $\begin{array}{l}\text { Parastitic } \\
\text { Protozoa }\end{array}$ & $\begin{array}{l}\text { Cryptosporidium parvum } \\
\text { Cyclospora histolyica } \\
\text { Entamoeba histolytica } \\
\text { Giardia intestinalis }\end{array}$ & $\begin{array}{l}\text { Cryptosporidiosis-watery diarrhoea, } \\
\text { abdominal cramps and pain } \\
\text { often asymptomatic; diarrhoea, } \\
\text { abdominal pain } \\
\text { Amoebiasis-often asymptomatic, } \\
\text { dysentery, abdominal discomfort, } \\
\text { fever, chills } \\
\text { Giardiasis- diarrhoea, abdominal } \\
\text { cramps, malaise, Weight loss }\end{array}$ \\
\hline Helminths & $\begin{array}{l}\text { Ascaris lumbricoides } \\
\text { Taenia solium/ saginata } \\
\text { Trichuris trichura } \\
\text { Hookworm } \\
\text { Schistosoma spp. (blood } \\
\text { fluke) }\end{array}$ & $\begin{array}{l}\text { Generally no or few symptomps; } \\
\text { wheezing; coughing; fever; enteritis; } \\
\text { pulmonary eosinophilia } \\
\text { Taeniasis } \\
\text { Trichuriasis-Unapparent through vague } \\
\text { digestive tract distress to emaciation } \\
\text { with dry skin and diarrhoea } \\
\text { Itch; rash; cough; anaemia; protein } \\
\text { deficiency } \\
\text { Schistosomiasis, bilharzias }\end{array}$ \\
\hline
\end{tabular}

Table3: Night Soil based Biogas Composition.

\begin{tabular}{|l|l|l|l|l|}
\hline Item & Night soil & FYM & Compost manure & Digested Slurry \\
\hline Nitrogen & $3.0-5.0$ & $0.5-1.0$ & $0.5-1.5$ & $1.4-1.8$ \\
\hline $\mathrm{P} 2 \mathrm{O},(\%)$ & $2.5-4.4$ & $0.5-0.8$ & $0.4-0.8$ & $1.1-2.0$ \\
\hline $\mathrm{K} 2 \mathrm{O}(\%)$ & $0.5-1.9$ & $0.5-0.8$ & $0.5-1.9$ & $0.8-1.2$ \\
\hline
\end{tabular}

Table 4: Composition of Spent Slurry from Night-Soil Biogas Plant.
Table 5: Pathogens and its harmful effects.

Acetic acid is digested to methane and carbon dioxide according to the following reaction

$$
\mathrm{C}_{2} \mathrm{H}_{4} \mathrm{O}_{2} \rightarrow \mathrm{CH}_{4}+\mathrm{CO}_{2}+\mathrm{E}_{\text {dig }}
$$

where $\mathrm{E}_{\mathrm{dig}}$ is the free energy released.

The combination of equation 3 and equation 4 results in equation 2. Hence the free energy released from equation 3 and equation 4 must be equal to that released in equation 2 .

$$
\mathrm{E}_{\mathrm{dig}}+191=207 \text {, hence } \mathrm{E}_{\text {dig }}=16 \mathrm{kcal} \mathrm{mol}^{-1}
$$

This shows that free energy released during the anaerobic digestion of acetic acid is only a fraction of $16 / 207=8$ percent of the free energy released during the aerobic oxidation of the same compound, the rest of the energy (92\%) being retained in the methane. Furthermore, with the relatively large release of chemical energy very little energy is locked up in the new microbial cells produced during the process, and thus the relative amount of new microbial cells formed as surplus sludge is also small [50]. 
The fact that dissolved oxygen is not needed for the process, that methane as a combustible gas has commercial value, and that the biomass production is relatively small makes the anaerobic digestion process ideal for the stabilisation of organic sludges, the treatment of concentrated organic industrial wastes and the production of methane gas from agricultural and domestic wastes [51].

Despite the advantages highlighted previously, the general acceptance and applicability of anaerobic digestion is only now beginning to rise within the last decade.

\section{Design parameters for sizing of biogas plants}

The optimum biogas production is achieved when the $\mathrm{pH}$ value of input mixture in the digester is between 6 and 7. The $\mathrm{pH}$ in a biogas digester is also a function of the retention time. Methanogenic bacteria are very sensitive to $\mathrm{pH}$ and do not thrive below a value of 6.5 . Loading rate is the amount of raw materials fed per unit volume of digester capacity per day. If the plant is overfed, acids will accumulate and methane production will be inhibited. Similarly, if the plant is underfed, the gas production will also be low. Retention time (also known as detention time) is the average period that a given quantity of input remains in the digester to be acted upon by the methanogens. For a night soil biogas digester, a longer retention time (70-80 days) is needed so that the pathogens present in human faeces are destroyed. The retention time is also dependent on the temperature [52]. The methanogens are inactive in extreme high and low temperatures. The optimum temperature is 35 degrees C. Satisfactory gas production takes place in the mesophilic range, between 25 degrees to 30 degrees C [53] (Table 7).

\section{Toxicity}

Mineral ions, heavy metals and the detergents are some of the toxic materials that inhibit the normal growth of pathogens in the digester. Small quantity of mineral ions (e.g. sodium, potassium, calcium, magnesium, ammonium and sulphur) also stimulates the growth of bacteria, while very heavy concentration of these ions will have toxic effect. Although there is a long list of the substances that produce toxicity on bacterial growth, the inhibiting levels of some of the major ones are given in (Table 8 ).

\begin{tabular}{|l|l|l|l|}
\hline Organism-disease & $\begin{array}{l}\text { Temperature } \\
\left({ }^{\circ} \mathbf{C}\right)\end{array}$ & $\begin{array}{l}\text { Retention Time } \\
\text { (days) }\end{array}$ & Kill Rate (\%) \\
\hline Salmonella spp. & $22-37$ & $6-20$ & $82-96$ \\
\hline Salmonella typhosa & $22-37$ & $6-20$ & 99 \\
\hline Mycobacterium tuberculosis & 30 & NA & 100 \\
\hline Ascaris lumbricoides & 29 & 15 & 90 \\
\hline Poliovirus-1 & 35 & 2 & 98.5 \\
\hline
\end{tabular}

Table 6: The kill rates of pathogens at different temperature and retention time during anaerobic fermentation.

\begin{tabular}{|l|l|}
\hline Design Parameters & Parameter Value \\
\hline $\mathrm{pH}$ & $6-7$ \\
\hline Digestion temperature & $20-35$ \\
\hline Retention time (HRT) & $40-100$ days \\
\hline Biogas energy content & $6 \mathrm{kWh} / \mathrm{m} 3$ \\
\hline Gas production per kg of human excreta & $0.020-0.028 \mathrm{~m} 3$ \\
\hline Gas requirement for cooking & $0.2-0.3 \mathrm{~m} 3 \mathrm{person}$ \\
\hline Gas requirement for lighting one lamp & $0.1-0.15 \mathrm{~m} 3 / \mathrm{hr}$ \\
\hline Source: Werner, Stohr ami Hccs (1989) & \\
\hline
\end{tabular}

Table 7: Design parameters for sizing of biogas plants.

\begin{tabular}{|l|l|}
\hline Inhibitors & Inhibiting Concentration \\
\hline Sulphate (SO4- - ) & $5,000 \mathrm{ppm}$ \\
\hline Sodium Chloride or Common salt $(\mathrm{NaCl})$ & $40,000 \mathrm{ppm}$ \\
\hline Nitrate $($ Calculated as $\mathrm{N})$ & $0.05 \mathrm{mg} / \mathrm{ml}$ \\
\hline Copper $(\mathrm{Cu}++)$ & $100 \mathrm{mg} / \mathrm{l}$ \\
\hline Chromium $(\mathrm{Cr}+++$ & $200 \mathrm{mg} / \mathrm{l}$ \\
\hline Nickel $(\mathrm{Ni+++})$ & $200-500 \mathrm{mg} / \mathrm{l}$ \\
\hline Sodium $(\mathrm{Na}+)$ & $3,500-5,500 \mathrm{mg} / \mathrm{l}$ \\
\hline Potassium $(\mathrm{K+})$ & $2,500-4,500 \mathrm{mg} / \mathrm{l}$ \\
\hline Calcium $(\mathrm{Ca}++)$ & $2,500-4,500 \mathrm{mg} / \mathrm{l}$ \\
\hline Magnesium $(\mathrm{Mg}++)$ & $1,000-1,500 \mathrm{mg} / \mathrm{l}$ \\
\hline Manganese $(\mathrm{Mn++})$ & Above $1,500 \mathrm{mg} / \mathrm{l}$ \\
\hline
\end{tabular}

Table 8: Toxic level of various inhibitors.

\section{Anaerobic digester/bio digesters/biogas plant}

The bio digester is a physical structure, commonly known as the biogas plant. Since various chemical and microbiological reactions take place in the biodigester, it is also known as bio-reactor or anaerobic reactor Anaerobic Digester or Bio digesters or Biogas plant. The main function of this structure is to provide anaerobic condition within it. As a chamber, it should be air and water tight. It can be made of various construction materials and in different shape and size. Construction of this structure forms a major part of the investment cost. Some of the commonly used designs for treating the night soil are discussed below (Table 9).

\section{Design of digester for night soil treatment}

KVIC Biogas plant: In KVIC design, the digester chamber is made of brick masonry in cement mortar. A mild steel drum is placed on top of the digester to collect the biogas produced from the digester. Thus, there are two separate structures for gas production and collection. With the introduction of fixed dome Chinese model plant, the floating drum plants became obsolete because of comparatively high investment and maintenance cost along with other design weaknesses. In Nepal, KVIC design plants have not been constructed since 1986.

Fixed dome biogas plant: Fixed dome biogas plant consists of an underground brick masonry compartment (fermentation chamber) with a dome on the top for gas storage. In this design, the fermentation chamber and gas holder are combined as one unit. This design eliminates the use of costlier mild steel gas holder which is susceptible to corrosion. The life of fixed dome type plant is longer (from 20 to 50 years) compared to KVIC plant.

Water kiosk biogas plant: The water kiosk biogas plant has a volume of $54 \mathrm{~m}^{3}$ with two expansion chambers. The underground structure is located about $0.5 \mathrm{~m}$ below surface. The required area for the toilet building and biogas plant is approximately $10 \times 15$ metres. It is not recommended to build any structures on top of the biogas plant. The dimensions of the plant were based on a sufficient settlement of solids which is achieved with a hydraulic retention time (HRT) of 5 days. The solids settle and remain in the system for digestion and biogas production. The system works like a gas tight septic tank. The solids-free effluent is flowing over to the sewer connection.

BCSIR biogas plant: In BCSIR Design, the present fixed biogas plants have an underground cylindrical shaped biogas digester constructed with brick walls and concrete. The digester is also connected to the outlet tank, which includes a hydraulic chamber, and bio-fertiliser pit. The size of the plant depends on the availability of raw materials and demand for gas. It works according to the principles 
Citation: Daisy A, Kamaraj S (2011) The Impact and Treatment of Night Soil in Anaerobic Digester: A Review. J Microbial Biochem Technol 3: 043-050. doi:10.4172/1948-5948.1000050

\begin{tabular}{|c|c|c|c|c|c|c|c|c|c|}
\hline Location & Design & $\begin{array}{l}\text { Developed } \\
\text { By }\end{array}$ & $\begin{array}{r}\text { Capacity } \\
\left(\mathbf{m}^{3}\right)\end{array}$ & \begin{tabular}{|l} 
HRT \\
(days)
\end{tabular} & Source & Uses & $\begin{array}{l}\text { Treated } \\
\text { effulent }\end{array}$ & Type of the project & Reference \\
\hline India & $\begin{array}{l}\text { Sulabh biogas } \\
\text { plant (Similar } \\
\text { Fixed dome) }\end{array}$ & Sulabh & $30-60$ & 30 & $\begin{array}{l}\text { Public toilet } \\
(1.5-2 \text { It / } \\
\text { person /day) }\end{array}$ & $\begin{array}{l}\text { Gas-Cooking, } \\
\text { Electricity } \\
\text { Sludge-Soil } \\
\text { Conditioning, } \\
\text { fertilizer }\end{array}$ & $\begin{array}{l}85 \% \\
\text { reduction of } \\
\text { BOD }\end{array}$ & $\begin{array}{l}\text { Community \& } \\
\text { Institutional }\end{array}$ & Jha \\
\hline India & $\begin{array}{l}\text { ANERT } \\
\text { (Similar Fixed } \\
\text { dome) }\end{array}$ & Sulabh & 35 & NP & $\begin{array}{l}1500 \\
\text { (medical } \\
\text { college cum } \\
\text { hospital } \\
\text { campus } \\
\text { Hospital) }\end{array}$ & $\begin{array}{l}\text { Gas- Electricity } \\
\text { Sludge-Soil } \\
\text { Conditioning, } \\
\text { fertilizer }\end{array}$ & NP & $\begin{array}{l}\text { Community \& } \\
\text { Institutional }\end{array}$ & $\begin{array}{l}\text { Dinesh Aggarwal, } \\
(2003)\end{array}$ \\
\hline Kenya & Water kiosk & WSTF & 54 & 5 & $\begin{array}{l}\text { Public toilet } \\
(1000 \text { nos/ } \\
\text { day })\end{array}$ & \begin{tabular}{|l|} 
Gas-cooking for \\
Cafe shop \\
Sludge-Soil \\
Conditioning
\end{tabular} & $\begin{array}{l}\text { Irrigation } \\
\text { water } \\
\text { Expected } \\
\text { reduction of } \\
\text { BOD is 30- } \\
40 \%\end{array}$ & $\begin{array}{l}\text { Urban \& } \\
\text { Demonstration }\end{array}$ & $\begin{array}{l}\text { (WSTF, 2009) } \\
(\mathrm{GTZ}, 2009)\end{array}$ \\
\hline Nepal & $\begin{array}{l}\text { Latrine-cum- } \\
\text { Biodigester. }\end{array}$ & & $\begin{array}{l}20 \\
\text { Gas } \\
\text { production-5.8" } \\
\text { /day }\end{array}$ & 70 & $\begin{array}{l}\text { Blooming } \\
\text { Lotus School } \\
(3010 \\
\text { children) }\end{array}$ & Gas-cooking & NP & CMS & CMS (1996) \\
\hline Eastern Nepal & $\begin{array}{l}\text { Community } \\
\text { latrine cum bio } \\
\text { digester (fixed } \\
\text { dome) }\end{array}$ & Chinese & 15 & 21 & $\begin{array}{l}10 \text { latrine } \\
(250 \text { nos/ } \\
\text { day) }\end{array}$ & $\begin{array}{l}\text { Gas-Household } \\
\text { use } \\
\text { Sludge- } \\
\text { Compost }\end{array}$ & NP & $\begin{array}{l}\text { Biogas support } \\
\text { Programme of } \\
\text { the Netherlands } \\
\text { Development } \\
\text { Organization }\end{array}$ & CMS (1999) \\
\hline Bangadesh & $\begin{array}{l}\text { Fixed Dome } \\
\text { BCSIR }\end{array}$ & BCSIR & 10" dia & $10-15$ & $\begin{array}{l}\text { Public toilet } \\
(200 \text { nos / } \\
\text { day) }\end{array}$ & $\begin{array}{l}\text { Gas-cooking } \\
\text { Sludge- } \\
\text { Vegetable } \\
\text { Cultivation }\end{array}$ & NP & Arambag Islami Trust & $\begin{array}{l}\text { Avizit Reaz Quazi } \\
\text { and. Refatul Islam } \\
(2005)\end{array}$ \\
\hline Maharastra,India & $\begin{array}{l}\text { Malaprabha } \\
\text { biogas plant }\end{array}$ & $\begin{array}{l}\text { Dr.S.V. } \\
\text { Mapuskar }\end{array}$ & NP & 45 & $\begin{array}{l}\text { Public Toilet } \\
(2.17 \text { lit / } \\
\text { person ) }\end{array}$ & $\begin{array}{l}\text { Gas-cooking } \\
\text { Sludge- Manure }\end{array}$ & NP & Community & $\begin{array}{l}\text { Martin Wafler } \\
(2009)\end{array}$ \\
\hline Delhi, India & $\begin{array}{l}\text { Community } \\
\text { toilet linked with } \\
\text { biogas plant }\end{array}$ & & $\begin{array}{l}1 \mathrm{cft} \text { of biogas } \\
\text { produced from } \\
1 \text { person /day }\end{array}$ & 30 & $\begin{array}{l}\text { Public toilet } \\
(1000 \text { nos / } \\
\text { day) }\end{array}$ & $\begin{array}{l}\text { Gas-cooking } \\
\text { Lighting, } \\
\text { Electricity }\end{array}$ & $\begin{array}{l}85 \% \\
\text { reduction of } \\
\text { BOD }\end{array}$ & Community & Jha (2005) \\
\hline Jebapur,India & KVIC & & 50 & NP & $\begin{array}{l}\text { School (400 } \\
\text { children) }\end{array}$ & $\begin{array}{l}\text { Gas-cooking } \\
\text { Sludge- Maize } \\
\text { crop }\end{array}$ & NP & $\begin{array}{l}\text { Ashramshalarun } \\
\text { by sh.kanhaiyalal } \\
\text { maharasj trust }\end{array}$ & $\begin{array}{l}\text { Ajay Chandak } \\
(2009)\end{array}$ \\
\hline
\end{tabular}

WSTF - Water Services Trust Fund

CMS - Consolidated Management Services Nepal (P) Ltd

BCSIR - Bangladesh Council for Science and Industrial Research

ANERT - Agency for Non Conventional Energy and Rural Technology

KVIC - Khadi and Village Industries Commission

NP - Not Provided

Table 9: Comparison of different types of Night soil based digesters.

of constant volume and changing pressure. When the rate of gas production is higher than that of gas consumption, pressure inside the digester rises and expels some digester contents into the outlet compartment. When the consumption is higher than production, pressure inside the digester falls and the expelled materials in the outlet compartment run back to the main digester.

Malaprabha biogas plant: The Malaprabha biogas plant comprise of 3 compartments. The first compartment is designed to provide for a HRT of 30 days and doubles-up as gasholder. In order to collect the biogas that is generated in the process of anaerobic digestion of black water, the first compartment is provided a gas tight cover made from reinforced cement concrete (R.C.C.). The second and third compartment provide for a total HRT of 15 days. The chambers act as compensation chambers and facilitate build up of gas pressure. There is an opening at the bottom of the wall separating the 1 st and the $2^{\text {nd }}$ chamber and an aperture in the wall separating the 2 nd and 3 rd chamber to facilitate flow of water through the biogas plant. The opening (1st to 2nd chamber) provides access to the sealed 1st compartment during construction and doubles-up as maintenance opening afterwards.
The biogas plant is provided a pressure release pipe that vents biogas before excess gas pressure may damage the plant. Depending on site conditions, the effluent from Malaprabha Biogas Plants may be drained to an existing drainage system, infiltrated locally or collected for reuse. The digester volume equals number of users into litres of water used for flushing (and anal cleansing, if applicable) per person per day into 45 days HRT. For digestion of night soil (i.e. excreta), optimum requirement of water is 2.17 litre per person.

Community biogas plant: In Insitu biogas system,Household biogas generators have been accepted because the connection between the latrine and the digester requires no contact with the waste, bypassing any taboos. Implementing the technology in a more community-based situation may have its limits but there is evidence that Community Biogas Plants have been implemented.

\section{Retention time}

In this review, the biogas plant are classified in four category based on the retention time (Table 10). Water Kiosk is coming under low retention time based biogas plant. The retention time of this plant 
is 5 days. But the reduction of BOD performance is very poor as 30$40 \%$. Sulabh model, Community latrine cum biodigester, and BCSIR, are coming under medium retention time based biogas plant. The retention time of BCSIR is 10 to 15 days. The retention time of Sulabh is 30 days. The BOD reduction of these two plants is $85 \%$. The retention time of Community latrine cum biodigester is 21 days. The retention time of Malaprabha biogas plant is 45 days. It is high retention time based biogas plant.The Hydraulic Retention Time (HRT) of Latrine cum bio digester is 70 days it is ensure that most of the pathogens are destroyed. It is very high retention time based biogas plant [54-66]

\section{Capacity}

In this review, the biogas plant are classified in three category based on the capacity (Table 11) Community latrine cum biodigester is a low size reactor because the capacity of the plant is $15 \mathrm{~m}^{3}$.Sulabh, ANERT, Latrine cum biodigester and BCSIR are coming under medium size reactor category. Since the capacity of Sulabh model have ranged from 30 to $60 \mathrm{~m}^{3}$ in various place of India. So it comes under both the Medium and high size reactor. The minimum requirement of water Sulabh model is taken as 1.5 to 2 litre per person per day. But the minimum requirement of water in Malaprabha biogas plant is 2.17 litre per person per day. Water kiosk and KVIC are high size reactor.

\section{Efficiency of biogas plant (COD or BOD reduction)}

The COD reduction efficiency is very important in the case of biogas plant performance. Since the pollution load of effluent is as to be reduced to the level of prescribed by the Pollution Control Board. Untilunless the reduction efficiency is very high. It is very difficult bring down the COD and BOD level to less than the value prescribed by the Pollution Control Board.COD level is less than $500 \mathrm{mg} / \mathrm{l}$ even $50 \%$ reduction will result in effluent is $250 \mathrm{mg} / \mathrm{l}$ prescribed limit by Pollution Control Board. If the effluent COD is more than the 1000 $\mathrm{mg} / \mathrm{l}$, the minimum COD reduction efficiency required more than $75 \%$. So that the effluent COD will be less than $250 \mathrm{mg} / \mathrm{l}$. Without knowing the influent COD we could not conclude the efficiency of the biogas plant. In most of the design the influent/ effluent COD details are not furnished.

\section{Future Perspective}

The literature and the present study demonstrate that it is possible to use the anaerobic digester to anaerobically treat Night soil when diluted appropriately. This holds an enormous potential for faecal wastes treatment in developing countries where majority of sanitation facilities are on-site systems. However before the system can be adopted on a scale similar to its acceptance for the treatment of domestic sewage in tropical and sub-tropical climatic conditions, it will be essential

\begin{tabular}{|l|l|l|}
\hline S.No & Category & No of days \\
\hline 1 & Low retention time based biogas plant & $<10$ \\
\hline 2 & Medium retention time based biogas plant & $11-30$ \\
\hline 3 & High retention time based biogas plant & $31-45$ \\
\hline 4 & Very high retention time based biogas plant & $>45$ \\
\hline
\end{tabular}

Table 10: Retention Time. In this review, the biogas plant are classified in four category based on the retention time.

\begin{tabular}{|l|l|l|}
\hline S.No & Category & No of days \\
\hline 1 & Low size reactor & $<15$ \\
\hline 2 & Medium size reactor & $16-35$ \\
\hline 3 & High size reactor & $>35$ \\
\hline
\end{tabular}

Table 11: Capacity. to carry out more experimental studies. In this regard the following suggestions are made for further research work:

1. Most of experiments similar undertaken in this research are for lesson period only. It should be undertaken over a much longer period to establish steady state conditions that will enable correct assessments of long term treatment efficiencies, optimal loading rates, optimal hydraulic retention times, suitable dilution ratio, and gas production potentials among others.

2. During such experiment, efforts should be made to minimise, if not completely eliminate, the loss of biogas due to leakages and also an analysis of the biogas produced must be carried out to determine the percentages of methane and carbon dioxide in the biogas.

3. Production of biogas is significantly affected due to drop in temperature. Thus, until now, this technology has been of little use in the higher altitude or cold climate. Therefore, research work needs to be initiated in view of increasing the efficiency of gas at the cold climate or in higher altitudes.

4. Research efforts should has undertaken to improve the designs of night soil based biogas plant.

5. Such long term experiments should provide the required information for optimum design and operation/maintenance guidelines when using the anaerobic digester for the treatment of night soil. Because Biogas production is diminished significantly in cold climate or at higher altitude, while the methodology for warming the digester lo raise the temperature seems sophisticated, costly and unaffordable to the ordinary people. For example the design propagated in Nepal is costly and no substantial research has been initiated to lower its cost for wider application of the technology.

6. Several studies carried out in the past have confirmed that there is an increase in mosquito breeding after the installation of biogas. Therefore, serious thinking needs to be given to solve this problem because of the fact that fatal disease like malaria can occur in the community due to unwanted proliferation of mosquitoes.

7. Still there is less awareness amongst the farming community pertaining to the utilization of bio-slurry as fertilizer. This aspect appears to be neglected in the future. Agriculturists and biogas promoters will be carried out sufficient demonstrations and experiments to convince the farmers about the added benefits of slurry as an organic fertilizer compared to Farm Yard Manure.

\section{Conclusion}

The review of human excreta studies shows that there are significant risks of gastro-intestinal infections exposed from untreated human excreta. Studies show that human excreta treatment by anaerobic method prior to reuse can reduce these risks, and provide some indication of the extent of Night soil treatment needed to protect exposed populations against risks from helminth, bacterial and viral infections. The anaerobic digestion process has proved the effectiveness in reducing the number of pathogens present in the faecal matters is 90 to $95 \%$. Approximately $80 \%$ of the nitrogen, about $50 \%$ of the phosphorus and nearly $60 \%$ of the potassium from urine, and about $11 \%$ of the nitrogen, $25 \%$ of the phosphorus and $21 \%$ of the potassium from the faeces can be recycled. The most common range for conversion rate of the anaerobic digestion processes is reported to be $30-40^{\circ} \mathrm{C}$ temperature range. The more sensitive methanogenic organisms have an optimal conversion rate in the $\mathrm{pH}$ range 6 - 7. Sulphide toxicity can be prevented provided the sulphate-sulphur concentrations in 
the influent is below $300-600 \mathrm{mg} / \mathrm{l}$ and the $\mathrm{pH}$ is kept well above 6.5 but within the optimal range for methanogenic organisms. Ammonia toxicity can also be prevented if $\mathrm{pH}$ values are in the neutral range, the influent total ammonia plus ammonium concentration is up to $4000 \mathrm{mg} \mathrm{N} / \mathrm{l}$, and the concentration of free ammonia kept well below $100 \mathrm{mg} / \mathrm{l}$. Even though the very low retention time of water kiosk can not be recommended in the pollution point of view. Since the BOD reduction is 30 to $40 \%$. The Sulabh and Community toilet linked with biogas plant recommended for treating the night soil. Since maximum reduction of $85 \%$ BOD obtained with moderate retention time of 30 days. Proper design, construction and operation of the biogas plant is ensure that there is no risk of pathogens in Slurry, especially give more biogas production, effective reduction of BOD. This is also necessary for achieving no emissions of hazardous gas emissions, high methane yield, and rich nutrient in fertilizer from night soil.

\section{References}

1. Patra SK, Datta PP (2000) Renewable Sources Of Energy: Potentials and Achievements. Technical Digest Issue - 6 .

2. Satyanarayan S, Rao NN, Ramakant S, Kaul SN (2003) Improvement in biogas yield by feed stock amendments in cattle dung Digesters $\mathrm{J}$ Rural Tech 1: pp4853.

3. Deshpande CV, Shanta S, Kaul SN (1998) Bioenergy Production through Biomethanation - A NewApproach. Encology 12: 23-28.

4. Shanta S (1977) Performance of Laboratory Digesters Receiving Mixed Feed of Cattle Dung and Night Soil, NEERI, Internal Report.

5. Olsen JE, Larsen HE (1987) Bacterial decimation times in anaerobic digestion of animal slurries. Biological Wastes 21: 153-168.

6. Doku IA (2003) The potential for the use of upflow anaerobic sludge blanket (UASB) reactor for the treatment of faecal sludges in Ghana, Ministere Des Affaires Etrangeres, Technical and Applied Research Unit Ghana.

7. Singh L, Alam SI, Ramana KV (1999) Effect of Fluctuating Temperature Regime on Psychrophilic Anaerobic Digestion of Nightsoil. Defence Science Journal 49:135-140.

8. Carrington EG, Harman SA, Pike EB (1982) Inactivation of Salmonella during anaerobic digestion of sewage sludge. J Appl Bacteriol 53: 331-334.

9. Kearney TE, Larkin MJ, Levett PN (1993) The effect of slurry storage and anaerobic digestion on survival of pathogenic bacteria. J Appl Bacteriol 74 86-93.

10. Pradt LA (1971) Some recent developments in night soil treatment. Water Research 5: 507-521

11. Mara DD (1976) Sewage Treatment in Hot Climates. John Wiley \& Sons, Chichester, UK.

12. Satyanarayan S, Kaul SN, Badrinath SD, Gadkari SK (1987) Anaerobic treatment of human wastes. Indian Journal of Environmental Protection 7: 5-10.

13. Case Study: Water Kiosks (2009) (GTZ, 2009)

14. Choi E, Oa SW, Lee JJ (1997) Nightsoil treatment plant converted into sequencing batch reactor to improve removal of pollutants and nutrients. Water Sci Technol 35: 233-240.

15. Mara DD, Caincross S (1989) Guidelines for the safe use of wastewater and excreta in agriculture and aquaculture. World Health Organisation, Geneva, Switzerland.

16. Caincross S, Feachem RG (1993) Environmental. Health Engineering in the Tropics: An Introductory Text. ( $2^{\text {nd }}$ edition $)$, John Wiley \& Sons, Chichester, UK.

17. Stoll U, Parameswaran K (1996) Treatment and disposal of domestic sewage sludge andnightsoil sludge for Bangkok. Water Sci Technol 34: 206-217.

18. Choi ES, Lee HS, Lee JW, Oa SW (1996) Another carbon source for BNR system. Water Sci Technol 34: 363-369.

19. Lentner C, Lentner C, Wink A (1981) Units of Measurement, Body Fluids, Composition of the Body, Nutrition. Geigy Scientific Tables. CIBA-GEIGY Ltd Basle Switzerland ISBN 0-914168-50-9.
20. Feachem RG, Bradley DJ, Garelick H, Mara D (1983) Sanitation and Disease. Health aspects of excreta and wastewater management. World Bank studies in water supply and sanitation. John Willey and Sons. New York.

21. Schouw NL, Danteravanich S, Mosbaek H, Tjell JC (2002) Composition of human excreta - a case study from Southern Thailand. Sci Total Environ $J$ 286: $155-166$.

22. Guyton AC (1992) Human physiology and mechanisms of disease. W. B. Saunders Co, Philadelphia, USA.

23. http://en.wikipedia.org

24. Drangert JO (1998) Fighting the urine blindness to provide more sanitation options. Water South Africa 24: 157-164.

25. www.madsci.org

26. Polprasert C (1995) Organic waste recycling. John Wiley \& Sons Ltd. London.

27. Vinneras B, Palmquist H, Balmer P, Weglin J, Jensen A, et al. (2006) The characteristics of household wastewater and biodegradable waste - a proposal for new Swedish norms. Urban Water 3: 3-11.

28. Jonsson H, Stintzing R, Vinneras B, Salomon E (2004) Guidelines on use of urine and faeces in crop production. Report 2004-2, Ecosanres, Stockholm Environment Institute, Stockholm, Sweden.

29. Frausto da Silva JJR, Williams RJP (1997) The biological chemistry of the elements - The inorganic chemistry of life. Oxford UK.

30. Berger EY (1960) Intestinal absorption and excretion. In: Comar C. L. \& Bronner F. (eds). Mineral Metabolism, 249-286.

31. Guyton AC (1986) Textbook of Medical physiology. W B Saunders Co Philadelphia USA.

32. Jonsson H, Baky A, Jeppsoon U, Hellström D, Karrman E (2005) Composition of urine, faeces, greywater and biowaste for utilization in the URWARE model. Urban water Report of the MISTRA Programme, Report 2005:6, Chalmers University of Technology, Gothenburg, Sweden.

33. Vinneras B, Palmquist H, Balmer P, Weglin J, Jensen A, et al. (1999) The composting toilet system book. A practical guide to choosing, planning and maintaining composting toilet systems, an Alternative to sewer and septic systems. The center for ecological sanitation prevention (CEPP), Concord, Massachusetts.

34. Jonsson H, Vinneras B (2004) Adapting the nutrient content of urine and faeces in different countries using FAO and Swedish Data. Peer reviewed paper in the proceedings of the $2^{\text {nd }}$ International Symposium on ecological sanitation, incorporating the $1^{\text {st }}$ IWA specialist group conference on sustainable sanitation Division 44, Environment and Infrastructure sector project ecosan; $7^{\text {th }}-11^{\text {th }}$ April, 2003, Lubeck, Germany. Published by GTZ, Postfach 5180, 65726 Eschborn, Germany.

35. Gao XZh, Shen T, Zheng Y, Sun X, Huang S, et al. (2002) Practical manure handbook. (In Chinese). Chinese Agricultural Publishing House. Beijing, China.

36. Pieper W (1987) Das Scheiss-Buch - Entstehung, Nutzung, Entsorgung menschlicher Fakalien (The shit book - production, use, Entsorgung human faeces; in Germany). Der Zweig 123, Werner Pieper and Grüne Kraft. Germany.

37. Pharmacia (2000) svenska folkets tarmvanor - Den största undersökningen någon-sin om magen, dess skötsel och våra attityder till det alra mest privata, (Pharmacia upjohn: Stockholm).

38. EA WAG (1995) SANDEC News No. 1.

39. Rahman MH, Mottalin MA, Bhuiyan MH (1996) A Study on Biogas Technology in Bangladesh, 22 ${ }^{\text {nd }}$ WEDC Conference, New Delhi pp340.

40. Updated Guidebook on Biogas Development-Energy Resources Development Series (1984) No. 27. United Nations. New York, USA.

41. Werner U, Stohr U, Hees N (1989) Biogas Plants in Animal Husbandry. GATE/ (GTZ) $\mathrm{GmbH}$.

42. Amrit BK, Jagan Nath S, Sundar B (2005) BIOGAS as Renewable Source of Energy in Nepal, Nepal.

43. Stenstrom TA (2001) Reduction efficiency of index pathogens in dry sanitation compared with traditional and alternative wastewater treatment systems. Internet dialogue on Ecological Sanitation (15th Nov.-20th Dec. 2001). 
Citation: Daisy A, Kamaraj S (2011) The Impact and Treatment of Night Soil in Anaerobic Digester: A Review. J Microbial Biochem Technol 3: 043-050. doi:10.4172/1948-5948.1000050

44. WHO (2006) Guidelines for the safe use of wastewater, excreta and greywater. Volume 4. Excreta and greywater use in agriculture. ISBN 9241546859.

45. Schonning C, Stenstrom TA (2004) Guidelines for the safe Use of Urine and Faeces in Ecological Sanitation. Report 2004-1. Ecosanres, SEI. Sweden.

46. Andrew B, Leo P, Subramanian SK (1978) Biogas Technology the Third World: A Multidisciplinary Review. International Development Research Centre, Ottawa, Canada.

47. McCarty PL (1982) One hundred years of anaerobic treatment. In Second International Symposium on Anaerobic Digestion (6-11 September 1981, Travemünde, Germany), Edited by Hughes et al. Elsevier Biomedical Press B. V., Amsterdam, Netherlands.

48. van Haandel PFC Catunda, Lettinga G (1996) The UASB Reactor for Industrial and Domestic Waste Water Treatment. In Environmental Waste Management: A European Perspective. Edited by Nigel Horan. John Wiley \& Sons, Chichester, UK.

49. van Haandel AC, Lettinga G (1994) Anaerobic Sewage Treatment: A Practical Guide for Regions with a Hot Climate. John Wiley \& Sons, Chichester, UK.

50. Mosey FE (1981) Anaerobic biological treatment of food industry waste waters. Water Pollution Control Federation. 80: 273.

51. Pretorius WA (1983) An overview of digestion processes. Water Science and Technology 15: 1-6.

52. Lagrange B (1979) Biomethane 2: Principles - Techniques Utilization. EDISUD, La Calade, 13100 Aix-en-Provence, France.

53. Lund MS, Andersen SS, Torry-Smith M (1996) Building of a Flexibility Bag Biogas Digester in Tanzania. Student Report. Technical University of Denmark, Copenhagen.

54. Ajay C (2009) 50 cum per day biogas project based on night soil plus food waste for primary tribal Ashramshala at Jebapur, Tal Sakri, Dist.dhule.
55. Avizit RQ, Islam ER The reuse of human excreta in Bangladesh Rural sanitation 19: $248-262$.

56. CMS (1996) Improvement in Environment and Sanitation through Anaerobic Digestion of Human Wastes, United Nations High Commissioner for Refugees, Kathmandu, Nepal.

57. CMS (1996) Biogas Technology: A Training Manual for Extension. Food and Agriculture Organization of the United Nations.

58. CMS (1999) Monitoring Report on Latrine-cum-Biodigester Installation at Pathari, United Nations High Commissioner for Refugees, Kathmandu, Nepal.

59. Aggarwal D (2003) The Energy and Resources Institute (TERI), New Delhi, India.

60. Jha PK (2005) Recycling and reuse of human excreta from public toilets through biogas generation to improve santiation, community health and environment.

61. Jha PK (2005) Sustainable Technologies for On-site Human Waste and Wastewater Management: Sulabh Experience.

62. Martin W (2009) Description of Malaprabha Biogas Plant in Pune District Maharashtra, India.

63. Mclnerney MJ, Bryant MP, Stafford DA (1980) Metabolic stages and energetics of microbial anaerobic digestion. In First International Symposium on Anaerobic Digestion, Edited by D. A. Stafford, A. D. Scientific Press, Cardiff, Wales.

64. The Biogas Technology in China (1989) Chengdu Biogas Research Institute, Chengdu, China.

65. WSTF (2009) Public sanitation concept of WSTF.

66. WSTF (2009) Public toilet management guideline of WSTF 